\title{
Research on Training Mode of Employment and Entrepreneurship Education in Higher Vocational Colleges
}

\author{
Wei WANG \\ Department of Computer \\ Wuhan Polytechnic \\ Wuhan 430074, China \\ 201519122@qq.com
}

\begin{abstract}
At present, China's higher vocational education is still lack of perfect employment and entrepreneurship education mechanism, so it is of great significance to build employment and entrepreneurship education training. This paper studies how to optimize employment and entrepreneurship education in vocational colleges and how to cultivate students' employment and entrepreneurship ability. Some concrete measures are given.
\end{abstract}

Keywords-higher vocational colleges; employment and entrepreneurship education; optimization strategy; specific measures

\section{CURRENT SitUATION OF EMPLOYMENT AND}

\section{ENTREPRENEURSHIP EDUCATION IN HIGHER VOCATIONAL} EDUCATION IN CHINA

China's entrepreneurship education appeared in 1997 and it boasts of more than ten years of history; but compared with developed countries in Europe and America, China's entrepreneurship education is still in the primary stage, extremely immature. Entrepreneurship education in higher vocational colleges is, even more, the case. Most of them are still at low level and deliver no signs of development, which is mainly reflected in the following aspects[1]:

\section{A. Lack of perfect employment and entrepreneurship education mechanism}

At present, some higher vocational colleges do not have a correct awareness of employment and entrepreneurship education, and cannot make scientific prediction of students' future innovation and entrepreneurship, resulting in the lack of relevant mechanism of employment and entrepreneurship education in some higher vocational colleges. Due to the lack of attention to employment and entrepreneurship education in higher vocational colleges, the educational funds invested by the schools are insufficient, which hinders the development of innovation and entrepreneurship education to a large extent. In addition, in actual teaching, schools and teachers fail to pay enough attention to employment and entrepreneurship, which leads to teachers' lack of guidance for students' employment and entrepreneurship education, resulting in lack of students' awareness of employment and entrepreneurship, seriously hindering students' future entrepreneurship development.

\section{B. Theory teaching and practice teaching are not consistent}

In the aspect of employment and entrepreneurship education in higher vocational colleges, due to the wrong estimation of employment and entrepreneurship education and the influence of traditional education and teaching mode, teachers often emphasize much on the explanation of students' employment and entrepreneurship theory in practical teaching. However, it neglects the cultivation of students' practical ability and fails to create a platform for students to show themselves in employment and entrepreneurship education, which results in the inconsistency between its theory and practice and the lack of certain effectiveness in the curriculum development of the education in higher vocational colleges.

\section{Teachers' strength is weak}

The teachers' strength is weak and the teaching effect is not an obvious part of entrepreneurship education in higher vocational colleges that is responsible for the employment of teachers, primary teachers and professional teachers from the school administration. Although such teachers have certain professional attainments, their working experience is in need, who can't offer comprehensive guidance for students employment and entrepreneurship education. Although some teachers are qualified for innovation and entrepreneurship education, most of them only teach at the theoretical level due to their insufficient understanding of innovation and entrepreneurship education and lack of experience in the development of practical courses. In addition, some higher vocational colleges do not have a clear understanding of the forms of employment and entrepreneurship, and in the process of carrying out the education, they usually only introduce basic contents to students in the form of one-sided lectures, resulting in insufficient overall teaching effect.

\section{IT IS OF GREAT SIGNIFICANCE TO CONSTRUCT THE CULTIVATION OF EMPLOYABILITY AND ENTREPRENEURSHIP EDUCATION}

\section{A. Theoretical value}

We will further explore a competency-oriented talent training model for entrepreneurship education. The theoretical 
education, practical education, practice education and hands-on education the four major module integration of entrepreneurship education in higher vocational colleges is a systematic project, so as to better reflect higher vocational colleges in the new period "university-enterprise cooperation and work-integrated learning" concept, cultivate innovative practical talents to adapt to the market economy development. It enjoys important theoretical value.

We should construct the general path of entrepreneurship education and training in higher vocational colleges. In exploring the system of entrepreneurship education, Nanjing Polytechnic College should form a virtuous circle system of interaction between government and school, school and enterprise, and school and school. It changes the past practice that entrepreneurship education in higher vocational colleges only emphasizes the inculcation of theoretical knowledge and ignores the cultivation of students' creative ability. Therefore, how to build the general path of entrepreneurship education and training is particularly urgent for higher vocational colleges, which is also consistent with the positioning of higher vocational colleges in cultivating high-skilled talents[2].

\section{B. Practical significance}

Firstly, entrepreneurship and innovation ability is the core ability for higher vocational colleges to foster students. It is crucial for individuals to stimulate creativity and innovation in various work fields. Secondly, entrepreneurship education starts from the reality of students and emphasizes the cultivation of students' self-consciousness, sense of participation and practical spirit through a combination of various educational means, so that students can master entrepreneurial skills. Thirdly, strengthening the cultivation of entrepreneurial ability of college students enables college graduates to "not only become job seekers, but also gradually become job creators", which is of great significance to the overall development of students' quality and ability.

Entrepreneurship education in higher vocational colleges mainly stays in the stage of theoretical teaching, which merely imparts knowledge, but pays less attention to the students' career cultivation in actual practical ability. It ignores students' all-round development, therefore, how to build the ability of the path of entrepreneurship education training is particularly urgent for higher vocational colleges, which is also in consistent with higher vocational colleges' cultivation orientation of high-skilled talents.

Social development is significant. To actively carry out the research on the training path of entrepreneurship education courses in higher vocational colleges is conducive to the largescale implementation of entrepreneurship education and the training of more future entrepreneurs and technological innovators. At present, China is stepping over the stage of "management economy" in western countries and rapidly moving towards the era of "entrepreneurial economy", that is, the stage of innovation-driven and entrepreneurial economic development[3]. At this historical stage, the implementation of entrepreneurship education in higher vocational colleges will be more beneficial to the establishment and development of small enterprises, thus promoting technological innovation and social and economic prosperity.

\section{EMPLOYMENT AND ENTREPRENEURSHIP EDUCATION} OPTIMIZATION STRATEGY IN HIGHER VOCATIONAL COLLEGES

\section{A. We will strengthen the team of teachers who find jobs and} start their own businesses

At present, there is a lack of double-qualified teachers in higher vocational colleges. Under such circumstances, higher vocational colleges should enhance the construction of the team of teachers for employment and entrepreneurship in combination with the current needs of employment and entrepreneurship education, so as to provide a solid foundation for the guidance of employment and entrepreneurship of students[4]. First of all, higher vocational colleges should establish a "double-qualified" teacher team. Double-qualified teachers should not only have professional theoretical knowledge, but also rich practical experience, and be able to control employment and entrepreneurship education as a whole. In addition, teachers should keep pace with the times, have strong innovative thinking, and establish a correct sense of employment and entrepreneurship. Only by constantly improving their own comprehensive quality can teachers guide students in employment and entrepreneurship and promote the good development of employment and entrepreneurship education in vocational colleges.

\section{B. Combine employment and entrepreneurship education with majors}

While carrying out entrepreneurship and employment education, higher vocational colleges insist on taking students' professional courses as the basis and infiltrating employment innovation consciousness into actual teaching work. Teachers should combine employment and entrepreneurship education with students' majors to realize the talent training plan. When carrying out professional knowledge teaching, teachers should be good at stimulating students' employment and entrepreneurship consciousness, mining students' employment and entrepreneurship ability, and injecting new power into students. In addition, in daily work, teachers should be skilled at accumulating employment and entrepreneurship materials, and integrating them with practical professional teaching, actively guiding students to carry out in-depth study on them, and forming a teaching form with characteristics of employment and entrepreneurship in vocational colleges.

\section{Reforming and innovating personnel training models}

Higher vocational colleges in the actual process of education development mainly aim at cultivating versatile applied talents for the society. In practical education and teaching, emphasis should be laid on the basis of students' theoretical knowledge and the cultivation of students' comprehensive ability[5]. Teachers should adhere to the combination of talent training and social development, the correct grasp of the trend of social development, the vision of teaching in the future development, hence improving the educational objectives of vocational colleges. In addition, higher vocational colleges should change the traditional 
concept of education and under the guidance of "mass entrepreneurship and innovation", it should strengthen the cultivation of students' "innovation ability", deepen the teaching reform, increase the intensity of talent training, push higher vocational education to the peak of education, and make contributions to the development of our society.

\section{THE INNOVATION OF TRAINING MODE OF EMPLOYMENT EDUCATION}

\section{A. Teaching concept innovation}

Mentors guide practice and practice feedback theory; indirect guidance brings active penetration. This teaching method correctly and reasonably deals with the relationship between theoretical and practical learning. To change the traditional learning theory and practice of teaching philosophy, using guide is complementary with mentor theory in the process of practice; autonomous learning theory makes students realize the inculcating theory from passive to active learning theory knowledge, changing the present situation of the lack of practice, namely students learn theory but forget the theory soon.

\section{B. Teaching purpose innovation}

Teachers should take the innovation thought training as the first and the engineering practical ability as the ultimate teaching goal. This teaching method rejects the traditional evaluation system which takes the examination score as the index while paying attention to the performance in the practice process including student, role and cooperation ability in the activity participation process.; at the same time, it is necessary to highlight the evaluation of the formation and improvement of students' innovative spirit and practical ability. The concern is whether students can put forward questions, analyze and summarize the knowledge they have learned, and make some discoveries. And gradually students in the process of learning starts to form questions, willing to explore, practice, and strive to learn from others' positive attitude. After graduation, students will be able to devote themselves to the front line of engineering with profound practical and theoretical basis, and dare to solve practical engineering problems of comprehensive talents.

\section{Adopt action-oriented teaching methods}

The action-oriented teaching method was first proposed by German scholars and was widely used in the field of German vocational education. The main feature of action-oriented teaching method is that education is not completed by schools, but by enterprises and schools; the school does not dominate the role, just plays the auxiliary role and it is actually dominated by enterprises. Employment requirements and conditions are put forward by the enterprise, and students choose appropriate vocational colleges and universities to study according to the requirements of the enterprise.

For China, considering the national conditions, there is no way to implement the training mode dominated by enterprises, but the basic action-oriented concept and teaching methods can be used for reference and application.

Action-oriented teaching method emphasizes the subjective initiative of students with students as the main body and teachers as the secondary body. Students can learn independently under the guidance of teachers, thus producing efficient learning benefits. The roles of teachers and students have changed greatly, and the role of teachers has changed from the traditional leading role of knowledge indoctrination and the leader of teaching organization to the role of guiding or consulting, learning facilitator and host. The teaching content breaks the traditional discipline system, and is reflected in the interdisciplinary, competency-based professional activities. It focuses on cultivating students' professional action ability, so that all students can become competent. The whole teaching process includes information collection, planning, decisionmaking, execution, inspection and evaluation, which constitute a "complete behavior pattern". The students focus on the ability to cooperate, discuss and summarize. In teaching, teachers should pay attention to the quality control and evaluation of students in the learning process, give priority to motivation, so that students can have a strong sense of achievement[6].

\section{SUMMARY}

To sum up, under the background of "mass entrepreneurship and innovation", higher vocational colleges should actively change their teaching concepts and accurately position the educational goals of higher vocational colleges. In the actual process of entrepreneurship education of employment work, we should enhance awareness of employment entrepreneurship and entrepreneurship education; strengthen the school professional team of employment; invest double effort in reforming the innovation personnel training mode; develop professional teachers and innovative undertaking to build strong entrepreneurial culture atmosphere; insist on the trend of social development to cultivate all-round entrepreneurial talents.

\section{REFERENCES}

[1] Ayitura Maiti Rouzi. Analysis on the Cultivation Strategies of College Students' Entrepreneurial Ability [J]. Modern Economic Information, 2016 (29): 137.

[2] Xu Guangyi, Ou Xiaoming. Empirical Research on Social Network, Entrepreneurial Learning and Entrepreneurial Ability of College Students [J]. Youth Exploration, 2017 (5): 70-77.

[3] Yu Xin. Analysis and Construction of Entrepreneurial Ability of College Students in China [J]. Heilongjiang Higher Education Research, 2013 (3): 80-82.

[4] Xia Li. Innovation on the Construction of School-Enterprise Cooperative Practical Teaching System in Entrepreneurship Training [J].Education and Teaching BBS, 2012 (18): 226-267.

[5] Yang Xiaohui. Bottlenecks and Strategic Choices in the Cultivation of College Students' Entrepreneurial Ability [J]. China Higher Education, 2010 (18): 42-44.

[6] Chen Guangzheng, Chen Jun. On the Cultivation of College Students Innovation and Entrepreneurship Ability from the Perspective of Informal Learning [J]. Education and Career, 2016 (10): 84-86. 